\title{
Effect of Postpartum Depression and Anxiety on Infant Development at 12 Months: A One-year Follow-up Study
}

\section{Postpartum Depresyon ve Anksiyetenin Çocuğun 12. Aydaki Gelişimi Üzerine Etkisi: Bir Yıllık İzlem Çalışması}

(1) Gizem Kara Elitok1, (1) Lida Bülbül2, (1) Selime Çelik Erden³, (1) Aslı Beşirli³, (1) Ali Bülbül1

1 University of Health Sciences Turkey, Șișli Hamidiye Etfal Training and Research Hospital, Clinic of Pediatrics, İstanbul, Turkey

2University of Health Sciences Turkey, Bakırköy Dr. Sadi Konuk Training and Research Hospital, Clinic of Pediatrics, İstanbul, Turkey

3University of Health Sciences Turkey, Șișli Hamidiye Etfal Training and Research Hospital, Clinic of Psychiatry, İstanbul, Turkey

\begin{abstract}
Introduction: To evaluate the effect of maternal postpartum depression (PPD) and anxiety disorder (AD) during the postnatal first year on infant development at 12 months.

Methods: This prospective study was conducted at the well child follow-up clinic. A total of 113 mother-infant pairs were included in the study. In the postnatal first month, faceto-face interviews were conducted with mothers in order to complete the questionnaire. At the end of postnatal 1, 3, 6 and 12 months, the Edinburgh Postpartum Depression scale (EPDS) and Beck Anxiety scale (BAS) were administered to mothers. Those who scored $\geq 13$ points in EPDS and/or $\geq 8$ in BAS underwent psychiatric interviews and the structured clinical interview for the DSM-IV scale was performed. Infant development was evaluated at 12 months using the Denver-II Developmental Screening test and Guide for Monitoring Child Development.
\end{abstract}

Results: The study was completed with 91 mother-infant pairs. Among the mothers, $23.1 \%(n=21)$ had a personal history of psychiatric disorder while $15.4 \%(n=14)$ had a family history of psychiatric disorders. The prevalence of PPD and AD was determined to be $10.9 \%$ and $25.2 \%$, respectively. We found that the children of mothers with PPD had a higher prevalence of developmental delay in the domain of play at 12 months $(p=0.048)$, while the children of mothers with AD had a higher prevalence of developmental delay in the domain of relating $(p=0.049)$.

Conclusion: PPD and AD affect not only mothers but also their children. Physicians conducting paediatric follow-up should evaluate maternal mental health and refer mothers for professional help if necessary.

Keywords: Postpartum depression, anxiety disorder, child development, perinatal mental disorders

\section{öZ}

Amaç: Doğum sonrası ilk yılda annelerin postpartum depresyon (PPD) ve anksiyete bozukluğunun (AB) çocuğun 12. aydaki gelişimi üzerine etkisini değerlendirmektir.

Yöntemler: Bu prospektif çalıșma sağlam çocuk izlem polikliniğinde yapıldı. Yüz on üç anne-çocuk ikilisi çalıșmaya katıldı. Doğum sonrası birinci ay sonunda annelerle yüz yüze kișisel bilgi anket formu dolduruldu. Postnatal 1., 3., 6. ve 12. ay sonunda annelere Edinburg Postpartum Depresyon ölçeği (EPDÖ) ve Beck Anksiyete ölçeği (BAÖ) verildi. EPDÖ puanı $\geq 13$ ve/veya BAÖ puanı $\geq 8$ olanlarla psikiyatrik görüşme yapıldı ve Ruhsal Bozuklukların Tanısal ve Sayımsal El Kitabı'na (DSM-IV) dayalı yapılandırılmış psikiyatrik görüşme ölçeği uygulandı. Çocukların gelișimi düzeltilmiş 12. ay sonunda Denver-II Gelişimsel Tarama testi ve Gelișimi İzleme ve Destekleme Rehberi ile değerlendirildi.

Bulgular: Çalıșma birinci yıl sonunda düzenli takipleri yapılan 91 anne-bebek ikilisiyle tamamlandı. Annelerin \%23,1'inin ( $n=21)$ öz geçmișinde, \%15,4'ünün $(n=14)$ soy geçmișinde psikiyatrik hastalık öyküsü vardı. PPD sıklığı \%10,9 ve AB sıklığı \%25,2 olarak saptandı. PPD'li annelerin çocuklarının 12. ay oyun alanındaki gelişimlerinin $(p=0,048), A B$ olan annelerin çocuklarının ise ilișki alanındaki gelișimlerinin $(p=0,049)$ gecikmeli olma sıklığı diğerlerine göre daha fazlaydı.

Sonuç: PPD ve AB sadece anneleri değil aynı zamanda çocuklarını da etkileyen bir durumdur. Bu nedenle çocuk sağlığı izlemi yapan hekimler, çocukların takibini yaparken annelerin ruhsal durumunu değerlendirmeli ve gerekirse uzman desteğine yönlendirmelidir.

Anahtar Kelimeler: Postpartum depresyon, anksiyete bozukluğu, çocuk gelişimi, perinatal zihinsel bozukluklar 


\section{Introduction}

Pregnancy and the postpartum period constitute a high-risk stage in women's lives in terms of developing mental disorders (1). Postpartum depression (PPD) is a common complication of pregnancy with a reported prevalence in western societies of $10 \%-15 \%$ and in Turkey of $15.4 \%-51.3 \%(2,3)$. It is defined as a depression attack occurring within 4 weeks after birth (4). Studies have reported that this period may last for up to one year (3).

Postnatal anxiety disorders (AD) are more common than depression (5). They may occur alone or in combination with PPD (6). It has also been reported that mothers with PPD have a higher possibility of developing $A D$ in the postnatal period $(6,7)$.

Parental mental health has a significant impact on infant development (1). Particularly, it was reported that chronic PPD disrupted mother-child interactions and led to cognitive, social, emotional and behavioural problems in children $(1,8,9)$. However, due to varied sociocultural structures across different societies, maternal mental disorders may have different effects on children. Although many studies have been conducted in Turkey to investigate the prevalence of PPD and related factors, only few studies have evaluated the effect of PPD on infant development $(3,4,10)$.

Therefore, this study aimed to evaluate the effect of PPD and AD on infant development at 12 months in Turkey.

\section{Methods}

This prospective cohort study was conducted at Şișli Hamidiye Etfal Training and Research Hospital between September 2015 and December 2016. The participants were informed about the study, and their oral and written consents were obtained. A total of 113 mothers who accepted to participate were included. Approval was obtained from the Ethics Committee of Șișli Hamidiye Etfal Training and Research Hospital (decision no: 536, date: 04.08.2015).

In the aforementioned hospital, the follow-up of children begins at the well child follow-up clinic at the end of the first postnatal month and continues periodically until the age of six years, assessing the growth and development of infants and providing recommendations to families in order to support such growth and development.

Mothers who applied to the well child clinic between $1^{\text {st }}$ September 2015 and $31^{\text {st }}$ December 2015 with infants chronologically at postnatal one month, and who did not fulfil the exclusion criteria were randomly invited to the study. One of the researchers conducted a face-to-face interview with each participating mother in order to complete the personal information questionnaire developed for this study.

This questionnaire was developed by two paediatricians and one psychiatrist using the current studies in the literature. The questionnaire consisted of a total of 44 questions including maternal sociodemographic characteristics (age, education, socio-economic status, number of live births, etc), PPD risk factors (maternal personal history of psychiatric disorder, whether the pregnancy was planned or not, relationship with spouse, etc) and information about birth and the infant (gender, gestation week, birth weight, mode of delivery, etc).
After completing the personal information questionnaire, the mothers were handed the Edinburgh Postpartum Depression scale (EPDS) and Beck Anxiety scale (BAS) to be completed in order to screen for PPD and anxiety. The completed scales were cross-checked by the researcher upon submission in order to have the blank questions completed.

The EPDS and BAS were performed on the mothers at the end of postnatal 1, 3, 6 and 12 months of their infants. In each of these four screenings, an EPDS score of $\geq 13$ and a BAS score of $\geq 8$ were considered as the risk group and psychiatric examinations of the mothers falling into this group were planned for diagnosis. The mothers were evaluated by the same two psychiatrists in the study team with a focus on depression and AD. For diagnostic evaluation, structured interviews based on the Diagnostic and Statistical Manual of Mental Disorders (DSM-IV) were conducted. The Structured Clinical Interview for DSM-IV (SCID-I) scale was performed. For those mothers who were diagnosed with PPD and/ or anxiety in SCID-I, a follow-up process was initiated by the psychiatrist researchers.

The Denver-II Developmental Screening test and the Guide for Monitoring Child Development (GMCD) were administered in order to assess the infants' development at the end of the corrected 12 months. We determined whether the infants' development was age appropriate and if not, which domains were delayed. The assessments were conducted by the same researcher.

\section{Exclusion Criteria}

Mothers with native language other than Turkish, illiterate mothers, with physical disorders complicating child care, infants with congenital anomalies, risky birth history (infants born at gestation week $<35$, perinatal asphyxia or neonatal resuscitation) or infants hospitalized in the neonatal intensive care within the first one month were excluded from the study.

\section{Scales Used in the Assessment of Maternal Depression and Anxiety}

The EPDS: It is the most common self-reported scale used for screening depression in the postpartum period, which is a four-point Likert-type scale consisting of a total of ten questions. The lowest possible score is zero and the highest is 30 . The Turkish adaptation was made by Engindeniz et al. (11) with a cut-off score of $\geq 13$.

The BAS: It is a Likert-type self-assessment scale with 21 symptom categories each having 4 choices. Each item is worth 0 to 3 points evaluated as follows: 8-15 points: Mild anxiety, 16-25 points: Moderate anxiety, 26-63 points: Severe anxiety. The Turkish validity and reliability were conducted by Ulusoy et al. (12).

The Structured Clinical Interview Scale - The Clinician Version for DSM-IV Axis I Diagnoses: It is a clinical interview structured by First et al. (13) for DSM-IV Axis I disorders. The Turkish validity and reliability have been completed (14).

\section{Scales Used in the Assessment of Infant Development}

The Denver-II Developmental Screening Test: It is a screening test used for assessing the development of children aged 0 to 72 months. The test form consists of four sections devoted to the developmental domains 
of personal-social, language, fine motor and gross motor skills. It was adapted and standardised into Turkish by Yalaz et al. (15).

The GMCD: It is a guide developed to prevent developmental problems and to direct the respective process towards early diagnosis and interventions. It is performed on children aged 0 to 42 months enabling the assessment and monitoring of the developmental domains of expressive and receptive language, gross and fine motor skills, play, relating and self-help. It was developed, internationally standardised and verified by Ozturk Ertem et al. (16). It is one of the few tools that possess adequate psychometric and feasibility criteria for use in lowand middle-income countries (17).

\section{Statistical Analysis}

SPSS 16.0 for Windows programme was used for statistical analysis. Descriptive statistics were expressed as counts and percentages for categorical variables. Rate comparisons were performed using the chisquare analysis in independent groups. The statistical alpha significance level was taken as $p<0.05$.

\section{Results}

The study was initiated with 113 mother-infant pairs, and completed at the end of the first year with 91 mother-infant pairs under regular follow-up. The study flow chart is shown in Figure 1. The maternal mean age was $30.5 \pm 5.7$ years and the maternal mean duration of education was $10.6 \pm 4.9$ years. Among the participants, $15.4 \%(n=14)$ had a family history of psychiatric disorder. In addition, $23.1 \%(n=21)$ of the mothers reported a personal history of psychiatric problem, whereas $4.4 \%(n=4)$ reported a psychiatric problem experiences in the previous pregnancy. The sociodemographic data of the participants is shown in Table 1.

During the one-year follow-up period, 48 mothers (52.7\%) scored high in the screening tests performed for PPD and anxiety, and were classified as the risk group. Fifteen of the mothers in the risk group were not diagnosed with any disorder and were classified as the healthy group along with those mothers who scored low in the scales, altogether making 58 mothers (63.7\%) not diagnosed by SCID-I. Also, 33 of the participating mothers (36.3\%) were diagnosed by SCID-I, namely 10 (10.9\%) were diagnosed with PPD and 23 (25.2\%) were diagnosed with $\mathrm{AD}$ (Figure 1)

According to the DENVER test, no differences were detected in the development at 12 months of the children whose mothers had PPD, AD or no disorders in the domains of personal-social, language, fine and gross motor skills ( $p=0.224, p=0.677, p=0.389, p=0.519$, respectively). The DENVER test results are shown in Table 2.

According to the GMCD, no differences were detected in the development at 12 months of the children whose mothers had PPD, AD or no disorders in the domains of expressive language, receptive language, motor skills and self-help ( $p=0.710, p=0.220, p=0.401, p=0.647$, respectively). On the other hand, differences were found in the development at 12 months of children whose mothers were in these three groups in terms of the play and relating domains. In the group of mothers with PPD, there were more children who had developmental delay in the domain of play $(p=0.048)$. Among the children of mothers with $A D$, there were more children with delayed development in the domain of relating $(p=0.049)$. These children's development at 12 months assessed according to the GMCD is shown in Table 3.

\section{Discussion}

In this study, the prevalence of maternal PPD and anxiety was 10.9\% and $25.2 \%$, respectively. These rates were similar to those of the previous studies. It is estimated that in low-and middle-income countries, perinatal mental disorders, predominantly consisting of PPD and anxiety, are observed in one sixth of pregnant women and one fifth of women in the postnatal period (9). In a study conducted in Pakistan, the prevalence of PPD was reported as $24 \%-56 \%$ in women (18). On the other hand, in a study conducted among Pakistani women living

\section{Table 1. Distribution of the sociodemographic data of the participants}

\begin{tabular}{|l|l|}
\hline & Mean \pm standard deviation \\
\hline Maternal age, years & $30.5 \pm 5.7$ \\
\hline Maternal duration of education, years & $10.6 \pm 4.9$ \\
\hline Monthly income, Turkish lira & $3.018 \pm 2.725$ \\
\hline Number of living children, $n$ & $2^{*}$ \\
\hline Infant's gestation week & $38.2 \pm 1.6$ \\
\hline Infant's birth weight, kg & $3,156 \pm 1,656$ \\
\hline & $\mathbf{n}, \%$ \\
\hline Sex & \\
\hline Male & $41(45.1)$ \\
\hline Female & $50(54.9)$ \\
\hline Maternal employment status & \\
\hline Employed & $28(30.8)$ \\
\hline Housewife & $63(69.2)$ \\
\hline Family type & \\
\hline Nuclear & $72(79.1)$ \\
\hline Extended & $19(20.9)$ \\
\hline Family history of psychiatric disorder & \\
\hline Yes & $14(15.4)$ \\
\hline No & $77(84.6)$ \\
\hline Personal history of psychiatric disorder & \\
\hline Yes & $21(23.1)$ \\
\hline No & $70(76.9)$ \\
\hline Maternal history of psychiatric problem in previous pregnancy \\
\hline Yes & $4(4.4)$ \\
\hline No & $87(95.6)$ \\
\hline Relationship with spouse & $71(78)$ \\
\hline Good & \\
\hline Mediocre & \\
\hline Bad & \\
\hline Was the pregnancy planned? & \\
\hline Yes & \\
\hline No & \\
\hline
\end{tabular}




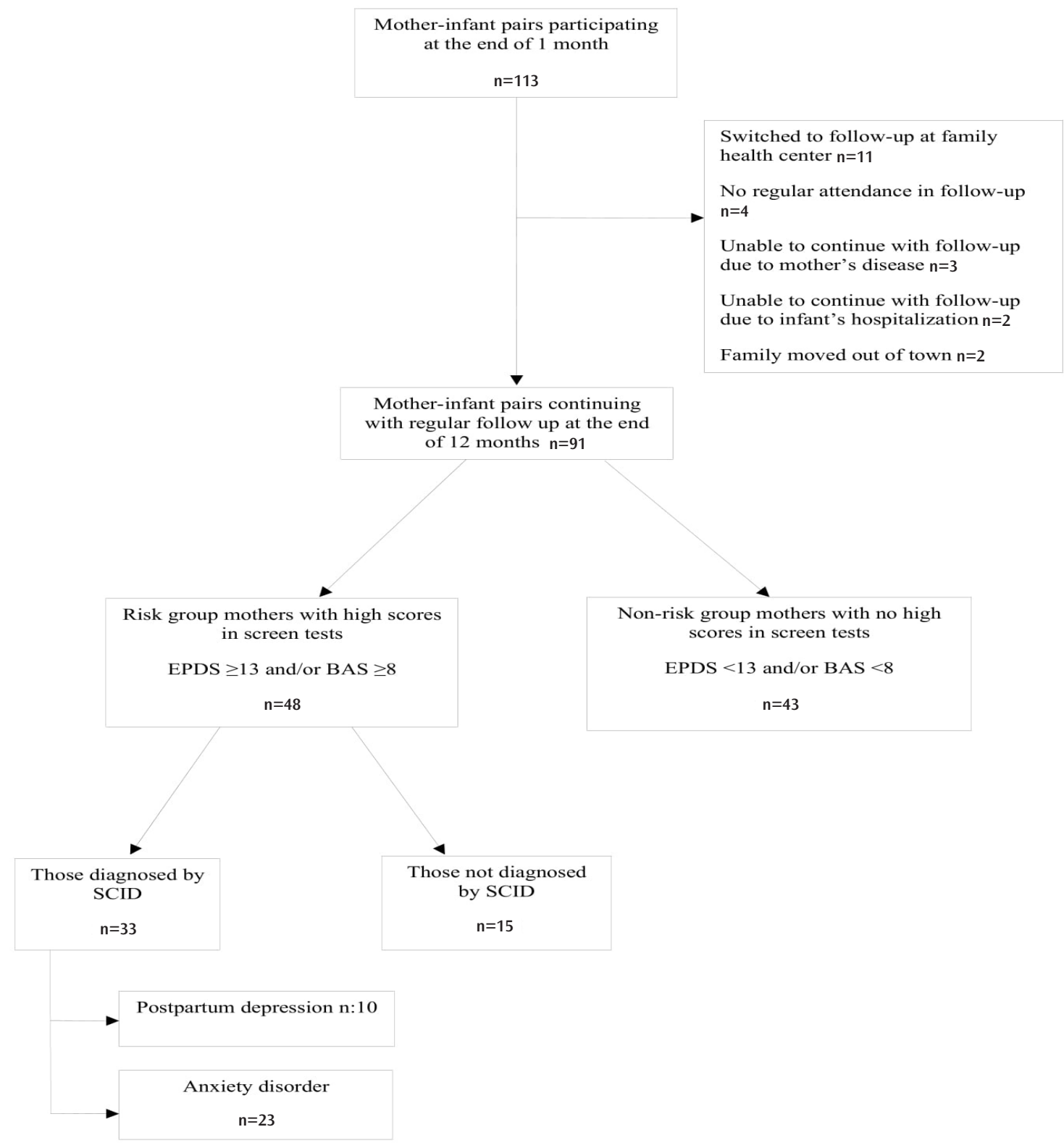

Figure 1. Study flow chart

EPDS: Edinburgh Postpartum Depression scale, BAS: Beck Anxiety scale, SCID: The structured clinical interview for DSM-IV

Table 2. Effect of postpartum depression and anxiety on infant development at 12 months DENVER results

\begin{tabular}{|c|c|c|c|c|c|}
\hline $\begin{array}{l}\text { DENVER } \\
\text { developmental domains }\end{array}$ & & $\begin{array}{l}\text { Postpartum depression } \\
n=10\end{array}$ & $\begin{array}{l}\text { Anxiety disorder } \\
n=23\end{array}$ & $\begin{array}{l}\text { Those not diagnosed by SCID } \\
n=58\end{array}$ & $p$ \\
\hline \multirow{2}{*}{ Personal-social } & Pass & 10 & 22 & 58 & \multirow{2}{*}{0.224} \\
\hline & Fail & 0 & 1 & 0 & \\
\hline \multirow{2}{*}{ Language } & Pass & 10 & 22 & 57 & \multirow{2}{*}{0.677} \\
\hline & Fail & 0 & 1 & 1 & \\
\hline \multirow{2}{*}{ Fine motor } & Pass & 9 & 23 & 55 & \multirow{2}{*}{0.389} \\
\hline & Fail & 1 & 0 & 3 & \\
\hline \multirow{2}{*}{ Gross motor } & Pass & 9 & 21 & 56 & \multirow{2}{*}{0.519} \\
\hline & Fail & 1 & 2 & 2 & \\
\hline
\end{tabular}

SCID: The structured clinical interview for DSM-IV 
Table 3. Effect of postpartum depression and anxiety on infant development at 12 months GMCD results

\begin{tabular}{|c|c|c|c|c|c|}
\hline $\begin{array}{l}\text { GMCD } \\
\text { developmental domains }\end{array}$ & & $\begin{array}{l}\text { Postpartum } \\
\text { depression } \\
\mathrm{n}=10\end{array}$ & $\begin{array}{l}\text { Anxiety disorder } \\
n=23\end{array}$ & $\begin{array}{l}\text { Those not diagnosed by SCID } \\
n=58\end{array}$ & p \\
\hline \multirow[t]{2}{*}{ Expressive language } & Age appropriate & 8 & 16 & 45 & \multirow{2}{*}{0.710} \\
\hline & Delayed & 2 & 7 & 13 & \\
\hline \multirow[t]{2}{*}{ Receptive language } & Age appropriate & 8 & 20 & 55 & \multirow{2}{*}{0.220} \\
\hline & Delayed & 2 & 3 & 3 & \\
\hline \multirow[t]{2}{*}{ Gross- fine motor skills } & Age appropriate & 8 & 21 & 54 & \multirow{2}{*}{0.401} \\
\hline & Delayed & 2 & 2 & 4 & \\
\hline \multirow[t]{2}{*}{ Relating } & Age appropriate & 10 & 21 & 58 & \multirow{2}{*}{0.049} \\
\hline & Delayed & 0 & 2 & 0 & \\
\hline \multirow[t]{2}{*}{ Play } & Age appropriate & 6 & 18 & 52 & \multirow{2}{*}{0.048} \\
\hline & Delayed & 4 & 5 & 6 & \\
\hline \multirow[t]{2}{*}{ Self-help } & Age appropriate & 9 & 22 & 56 & \multirow{2}{*}{0.647} \\
\hline & Delayed & 1 & 1 & 2 & \\
\hline
\end{tabular}

in England, the PPD prevalence was determined as approximately 17\% (19). In Egypt, the rate of depression and/or anxiety in the postnatal period was reported as $32.8 \%$ (7). In Canada, this rate was found to be $17 \%$ for anxiety and $4.8 \%$ for depression (20). The studies conducted in Turkey report various results depending on the cultural characteristics of the region of study, the postnatal timing of the study and the method used $(3,4)$. The number of studies based on SCID are limited, and PPD prevalence has been determined as 6.3\%-16.8\% $(21,22)$.

In the present study, we found that the prevalence of developmental delay at 12 months in the domain of play was higher in the children of mothers with PPD compared to those without depression. Regarding the children of mothers with $\mathrm{AD}$, it was observed that the prevalence of developmental delay at 12 months in the domain of relating was higher. This may be due to the fact that such mothers may be unable to spare time to playing with their children or to provide the stimulants appropriate to support their children's development and the challenges in mother-child interaction. In a study on this matter, it was determined that mothers suffering from depression were less likely play to with their babies, show picture books or talk to them compared to mothers without depression (23).

In this study, we did not find any differences in the development at 12 months of the children whose mothers had PPD, AD or no disorders in terms of the domains of expressive language, receptive language, gross motor skills, fine motor skills and self-help. There are many studies in this regard in the literature; however, only one study was previously conducted in Turkey regarding this matter. In a study analysing the effect of PPD on breastfeeding and infant development, Salgın et al. (10) performed the EDB scale to 100 mothers three times in the first six months. However, at the end of 15 months, only 55 infants could be reached to perform the DENVER test. There was no statistically significant difference in the children of mothers with or without depression as a result of the DENVER test conducted at 15 months.
In a systematic review, it has been reported that maternal postnatal stress contributes to delayed cognitive and socio-emotional development in infants (24). Black et al. (8) reported that the infants of mothers with PPD attain lower levels of cognitive, motor and orientation/engagement skills at 6-12 months compared to those without PPD. A study conducted in Bangladesh reported developmental delays at 6-8 months in the motor skills of infants whose mothers had depression at 2-3 months postpartum (25). Another study conducted in Greece reported that infants with mothers suffering from PPD scored lower points in fine motor development at 18 months than the children of those without PPD (26). Another study analysing the effect of PPD and anxiety on infant development indicated that infants with mothers suffering from depression had developmental delays in cognitive, fine-gross motor and language domains in comparison to the children of those without depression. The aforementioned study also determined that mother's depression predisposes the child to approximately a 6-fold risk of being delayed in terms of emotional development (18).

The development a child's vocabulary is affected by various factors such as an interactive and stimulating environment, socio-economic status and relationship with parents (18). Quevedo et al. (27) determined that in the postnatal period, the children of mothers who had undergone depression stood a higher risk of developmental delay in the language domain at 12 months. Further, it was also reported that the duration of maternal depression was related to developmental delays in language $(27,28)$.

Studies have reported that maternal AD is correlated with infant socioemotional development and behavioural difficulties (1). Babies of socially anxious mothers may develop similar behaviour such as fear and avoiding strangers (1). It has also been determined that antenatal anxiety is influential not only during infancy but also at school age manifested by lower success in exams and disrupted executive functions $(29,30)$. 
It has been reported that in case of high socio-economic status, availability of social support and short-termed maternal mental disorder, the effect on children is lower (1). In a study conducted on Pakistani mothers and children living in England, the BAYLEY III development scale was performed on the infants at 6 months. This study found that the only infant developmental domain significantly correlated with PPD is adaptive behaviour (communication, play, selfdirection and social skills) (19). The results of the aforementioned study are similar to those of our study. In the present study, one of the reasons why infant developmental domains other than play and relating were unaffected by maternal depression and AD may be that the study was conducted at a Well Child Clinic. Each visit involves recommendations given to mothers to support infant growth and development. In this way, before any developmental delay in children can occur, families are already aware of the significance of social support to be provided to mothers.

The strengths of this study consist of the fact that this was a prospective study, which followed-up the mother-child pairs for one year; the mothers were assessed for PPD and anxiety at four time points during this period, and the diagnosis for PPD and AD was made using the SCID-I performed by a psychiatrist instead of self-assessment reports.

The limitation of this study is that there were more mothers at the beginning of the study, but the sample group diminished as the mothers did not regularly participate in the follow-up or completely discontinued it.

\section{Conclusion}

In the present study, the prevalence of maternal PPD was found as $10.9 \%$ and anxiety as $25.2 \%$. It was determined that the children of mothers with PPD had a higher prevalence of developmental delay in the domain of play at 12 months whereas the children of mothers with $\mathrm{AD}$ had a higher prevalence of developmental delay in the domain of relating. According to this study, maternal depression and AD affect not only the mothers themselves but also their children. Therefore, assessing maternal mental health in paediatric follow-up especially during the first year is crucial for optimal child development. Developmental delays in children may be prevented by providing early diagnosis and appropriate support to those mothers suffering from mental health issues.

\section{Ethics}

Ethics Committee Approval: Approval was obtained from the ethics committee of Sişli Hamidiye Etfal Training and Research Hospital (decision no: 536, date: 04.08.2015).

Informed Consent: The participants were informed about the study, and their oral and written consents were obtained.

Peer-review: Externally peer-reviewed.

Authorship Contributions: Surgical and Medical Practices - G.K.E., S.Ç.E., A.B.; Concept - G.K.E., L.B.; Design - G.K.E., A.Bü.; Data Collection or Processing - G.K.E., S.C..E., A.B.; Analysis or Interpretation - L.B., A.Bü.; Literature Search - G.K.E., L.B.; Writing - G.K.E., S.Ç.E., A.Bü.
Conflict of Interest: No conflict of interest was declared by the authors.

Financial Disclosure: The authors declared that this study received no financial support.

\section{References}

1. Stein A, Pearson RM, Goodman SH, Rapa E, Rahman A, McCallum M, et al. Effects of perinatal mental disorders on the fetus and child. Lancet 2014; 384: 1800-19.

2. Üstgörül S, Yanıkkerem E. Psychosocial health of women during pospartum period and affecting risk factors. JAREN 2017; 3: 61-8.

3. Ay F, Tektaș E, Mak A, Aktay N. Postpartum depression and the factors affecting it: 2000-2017 study results. J Psychiatric Nurs 2018; 9: 147-52.

4. American Psychiatric Association. Diagnostic and Statistical Manual of Mental Disorders, Fourth Edition, Text Revision. Washington, DC, 2000.

5. Brockington I. Diagnosis and management of post-partum disorders: a review. World Psychiatry 2004; 3: 89-95.

6. Falah-Hassani K, Shiri R, Dennis CL. Prevalence and risk factors for comorbid postpartum depressive symptomatology and anxiety. J Affect Disord 2016; 198: $142-7$.

7. Wassif OM, Abdo AS, Elawady MA, Abd Elmaksoud AE, Eldesouky RS. Assessment of postpartum depression and anxiety among females attending primary health care facilities in Qaliubeya governorate, Egypt. J Environ Public Health doi: 10.1155/2019/3691752

8. Black MM, Baqui AH, Zaman K, Mcnary SW, Le K, Arifeen SE, et al. Depressive symptoms among rural Bangladeshi mothers: implications for infant development. J Child Psychol Psychiatry 2007; 48: 764-72.

9. Surkan PJ, Patel SA, Rahman A. Preventing infant and child morbidity and mortality due to maternal depression. Best Pract Res Clin Obstet Gynaecol 2016; 36: 156-68.

10. Salgın A, Gökçay G, Yücel B, Polat A, Baysal SU, Sahip Y, et al. Effects of postpartum depression on breastfeeding and child development. J Ist Faculty Med 2007; 70: 70-3.

11. Engindeniz A, Küey L, Kültür S. Edinburgh doğum sonrası depresyon ölçeği Türkçe formu geçerlilik ve güvenilirlik çalıșması. 1st ed. Ankara: Psikiyatri Derneği Yayınları; 1996.p.51-2.

12. Ulusoy M, Sahin NH, Erkmen H. Turkish version of the Beck Anxiety Inventory: Psychometric properties. J Cogn Psychother 1998; 12: 163-72.

13. First MB, Spitzer RL, Gibbon M, Williams JB. Structured Clinical Interview for DSM-IV axis I disorders. Clinical Version (SCID-CV). Washington, DC: American Psychiatric Press; 1996.

14. Çorapçıoğlu A, Aydemir Ö, Yıldız M, Esen-Danacı A, Köroğlu E. DSM-IV Eksen I Bozuklukları için Yapılandırılmış Klinik Görüșme, Klinik Versiyon. Ankara; Hekimler Yayın Birliği: 1999.

15. Yalaz K, Anlar B, Bayoğlu B. Denver II Gelișimsel Tarama Testi "Türkiye Standardizasyonu”. Ankara; Gelișimsel Çocuk Nörolojisi Derneği: 2011.

16. Ozturk Ertem I, Krishnamurthy V, Mulaudzi MC, Sguassero Y, Bilik B, Srinivasan R, et al. Validation of the International Guide for Monitoring Child Development demonstrates good sensitivity and specificity in four diverse countries. Acta Paediatr 2019; 108: 1074-86.

17. Fischer VJ, Morris J, Martines J. Developmental screening tools: feasibility of use at primary healthcare level in low- and middle-income settings. J Health Popul Nutr 2014; 32: 314-26.

18. Ali NS, Mahmud S, Khan A, Ali BS. Impact of postpartum anxiety and depression on child's mental development from two peri-urban communities of Karachi, Pakistan: a quasi-experimental study. BMC Psychiatry 2013; 13: 274. 
19. Husain N, Cruickshank JK, Tomenson B, Khan S, Rahman A. Maternal depression and infant growth and development in British Pakistani women: a cohort study. BMJ Open 2012; 2: e000523.

20. Fairbrother N, Janssen P, Antony MM, Tucker E, Young AH. Perinatal anxiety disorder prevalence and incidence. J Affect Disord 2016; 200: 148-55.

21. Akman C, Uguz F, Kaya N. Postpartum-onset major depression is associated with personality disorders. Compr Psychiatry 2007; 48: 343-7.

22. Akçalı Aslan P, Aydın N, Yazııı E, Aksoy AN, Kirkan TS, Daloglu GA. Prevalence of depressive disorders and related factors in women in the first trimester of their pregnancies in Erzurum, Turkey. Int J Soc Psychiatry 2014; 60: 809-17.

23. McLearn KT, Minkovitz CS, Strobino DM, Marks E, Hou W. Maternal depressive symptoms at 2 to 4 months postpartum and early parenting practices. Arch Pediatr Adolesc Med 2006; 160: 279-84.

24. Kingston D, Tough S, Whitfield H. Prenatal and postpartum maternal psychological distress and infant development: a systematic review. Child Psychiatry Hum Dev 2012; 43: 683-714.

25. Nasreen HE, Kabir ZN, Forsell Y, Edhborg M. Impact of maternal depressive symptoms and infant temperament on early infant growth and motor development: results from a population-based study in Bangladesh. J Affect Disord 2013; 146: 254-61.
26. Koutra K, Chatzi L, Bagkeris M, Vassilaki M, Bitsios P, Kogevinas $M$. Antenatal and postnatal maternal mental health as determinants of infant neurodevelopment at 18 months of age in a mother-child cohort (Rhea Study) in Crete, Greece. Soc Psychiatry Psychiatr Epidemiol 2013; 48: 1335-45.

27. Quevedo LA, Silva RA, Godoy R, Jansen K, Matos MB, Tavares Pinheiro KA, et al. The impact of maternal post-partum depression on the language development of children at 12 months. Child Care Health Dev 2012; 38: 420-4.

28. Brennan PA, Hammen C, Andersen MJ, Bor W, Najman JM, Williams GM. Chronicity, severity, and timing of maternal depressive symptoms: relationships with child outcomes at age 5. Dev Psychol 2000; 36: 759-66.

29. Galler JR, Ramsey FC, Harrison RH, Taylor J, Cumberbatch G, Forde V. Postpartum maternal moods and infant size predict performance on a national high school entrance examination. J Child Psychol Psychiatry 2004; 45: 1064-75.

30. Buss C, Davis EP, Hobel CJ, Sandman CA. Maternal pregnancy-specific anxiety is associated with child executive function at 6-9 years age. Stress 2011; 14 665-76. 